Article

\title{
A Small Study of Bacterial Contamination of Anaerobic Digestion Materials and Survival in Different Feed Stocks
}

\author{
Lauren Russell ${ }^{1,2}$, Paul Whyte ${ }^{2}$, Annetta Zintl ${ }^{2}{ }^{-}$, Stephen Gordon ${ }^{2}$, Bryan Markey ${ }^{2}$, \\ Theo de Waal ${ }^{2}$, Enda Cummins ${ }^{3}$, Stephen Nolan ${ }^{4}$, Vincent O'Flaherty ${ }^{4}$, Florence Abram ${ }^{4}$, \\ Karl Richards ${ }^{5}$, Owen Fenton ${ }^{5}$ (D) and Declan Bolton 1 ,* \\ 1 Teagasc Food Research Centre, Ashtown, Dublin 15, Ireland; lauren.russell@teagasc.ie \\ 2 School of Veterinary Medicine, University College Dublin, Belfield, Dublin 4, Ireland; \\ paul.whyte@ucd.ie (P.W.); annetta.zintl@ucd.ie (A.Z.); stephen.gordon@ucd.ie (S.G.); \\ bryan.markey@ucd.ie (B.M.); theo.dewall@ucd.ie (T.d.W.) \\ 3 School of Biosystems and Food Engineering, University College Dublin, Belfield, Dublin 4, Ireland; \\ enda.cummins@ucd.ie \\ 4 School of Natural Sciences, National University of Ireland, Galway, Ireland; stiofnolan@gmail.com (S.N.); \\ vincent.oflaherty@nuig.ie (V.O.); florence.abram@nuigalway.ie (F.A.) \\ 5 Teagasc Environmental Research Centres, Johnstown Castle, Wexford, Ireland; \\ karl.richards@teagasc.ie (K.R.); owen.fenton@teagasc.ie (O.F.) \\ * Correspondence: Declan.Bolton@teagasc.ie
}

Received: 20 July 2020; Accepted: 20 September 2020; Published: 22 September 2020

\begin{abstract}
If pathogens are present in feedstock materials and survive in anaerobic digestion (AD) formulations at $37^{\circ} \mathrm{C}$, they may also survive the $\mathrm{AD}$ process to be disseminated in digestate spread on farmland as a fertilizer. The aim of this study was to investigate the prevalence of Salmonella spp., Escherichia coli O157, Listeria monocytogenes, Enterococcus faecalis and Clostridium spp. in AD feed and output materials and survival/growth in four formulations based on food waste, bovine slurry and/or grease-trap waste using International Organization for Standardization (ISO) or equivalent methods. The latter was undertaken in $100 \mathrm{~mL}$ Ramboldi tubes, incubated at $37^{\circ} \mathrm{C}$ for $10 \mathrm{~d}$ with surviving cells enumerated periodically and the $\mathrm{T}_{90}$ values (time to achieve a $1 \log$ reduction) calculated. The prevalence rates for Salmonella spp., Escherichia coli O157, Listeria monocytogenes, Enterococcus faecalis and Clostridium spp. were 3, 0,5, 11 and 10/13 in food waste, 0, 0, 2, 3 and 2/3 in bovine slurry, $1,0,8,7$ and 8/8 in the mixing tank, 5, 1, 17, 18 and $17 / 19$ in raw digestate and $0,0,0,2$ and 2/2 in dried digestate, respectively. Depending on the formulation, $\mathrm{T}_{90}$ values ranged from 1.5 to $2.8 \mathrm{~d}$, 1.6 to $2.8 \mathrm{~d}, 3.1$ to $23.5 \mathrm{~d}, 2.2$ to $6.6 \mathrm{~d}$ and 2.4 to $9.1 \mathrm{~d}$ for Salmonella Newport, Escherichia coli O157, Listeria monocytogenes, Enterococcus faecalis and Clostridium sporogenes, respectively. It was concluded that $\mathrm{AD}$ feed materials may be contaminated with a range of bacterial pathogens and L. monocytogenes may survive for extended periods in the test formulations incubated at $37^{\circ} \mathrm{C}$.
\end{abstract}

Keywords: Salmonella spp.; Escherichia coli O157; Listeria monocytogenes; Enterococcus faecalis; Clostridium spp.; anaerobic digestion; digestate; pathogens; sustainable farming

\section{Introduction}

Anaerobic digestion (AD) is a cheap and efficient method for processing the large amounts of organic waste produced by farming (manures and slurries), food processing and sewage treatments (sludge) while contributing to international renewable energy targets. Co-digestion of combined wastes produces biogas (methane and carbon dioxide) and digestate, a nutrient rich fertilizer [1] while 
recycling nutrients from biowaste back into food production (an important activity in sustainable farming) [2]. In its most basic form, $\mathrm{AD}$ involves mechanical pretreatment of the feed waste materials to reduce particle size and mix the formulations, followed by anaerobic digestion, which produces biogas and digestate, the latter of which is usually subject to a treatment (pasteurization or drying) before use as a soil fertilizer (Figure 1).

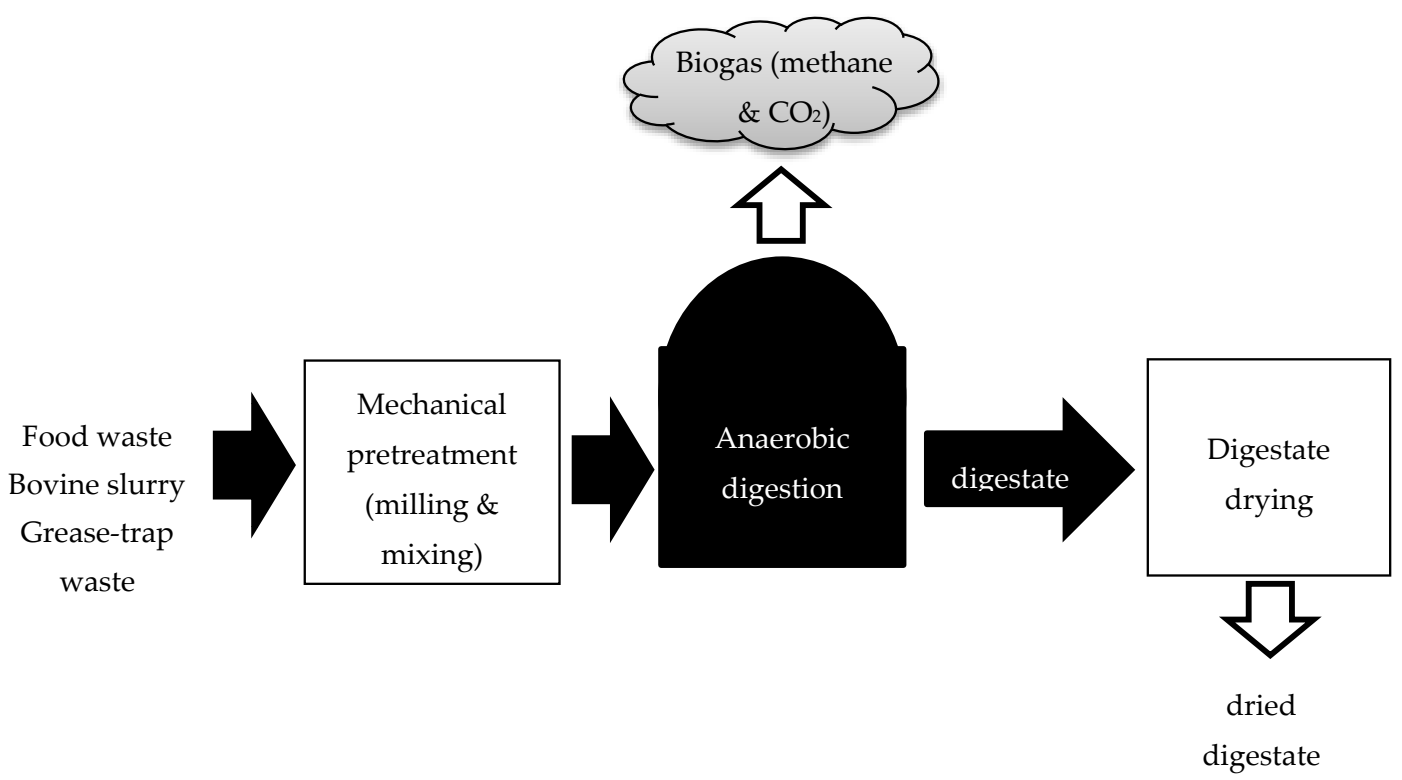

Figure 1. The basic steps in the anaerobic digestion process.

There are four stages in anaerobic digestion; hydrolysis, acidogenesis, acetogenesis and methanogenesis [3]. During hydrolysis the lipids, carbohydrates and protein present in the feed materials are broken down into fatty acids, sugars and amino acids, respectively. This is followed by acidogenesis, during which fermentative bacteria produce volatile fatty acids (VFAs), including propionic acid, butyric acid, acetic acid as well as ethanol, ammonia, carbon dioxide and hydrogen sulphide $\left(\mathrm{H}_{2} \mathrm{~S}\right)$. In the third stage (acetogenesis), the products of acidogenesis are converted into acetic acid, carbon dioxide and hydrogen while during methanogenesis (fourth stage), the products of the preceding stages are converted into methane, carbon dioxide and water [4]. The byproduct, digestate, is a nutrient rich fertilizer.

However, feedstocks may be contaminated with a range of bacterial, viral and parasitic pathogens of veterinary and public health concern [5], which may survive the process, depending on a combination of factors including initial load, feedstock, microbial competition, $\mathrm{pH}$, temperature and ammonia production [6], to be disseminated on farms in contaminated digestate [2,7,8]. Thus, EC Regulations $1069 / 2009$ and $142 / 2011$ require that $\mathrm{AD}$ raw materials or digestate must be heat treated at $70^{\circ} \mathrm{C}$ or $90^{\circ} \mathrm{C}$ for a minimum of $60 \mathrm{~min}$ or equivalent. Regardless, it is generally agreed that such treatments are only sufficient to kill vegetative bacteria like Salmonella, Listeria and Escherichia coli, while spore-forming organisms such as Clostridium spp. will survive. The application of digestate as a fertiliser is therefore banned in some countries [9].

Farm based AD plants in Ireland currently operate at mesophilic temperatures and typically co-digest animal slurry with food waste [10]. Data on bacterial contamination and survival during the different stages of the $\mathrm{AD}$ process is limited. Although the process parameters such as temperature are set to optimise biogas production, other factors such as the composition of feedstock and retention time could be manipulated, if necessary, to promote the destruction of target pathogenic bacteria without negatively impacting on the efficiency of the process [11]. The aims of this study were to test a range of AD input and output materials for the presence of Salmonella spp., E. coli O157, L. monocytogenes, Enterococcus faecalis and Clostridium spp. and to investigate the survival of representative strains of 
these bacteria in four $\mathrm{AD}$ feedstock materials/formulations, stored at $37^{\circ} \mathrm{C}$ in a laboratory-scale batch system previously used in similar studies [12].

\section{Materials and Methods}

\subsection{Pathogen Evaluation/Survey}

\subsubsection{AD Samples}

Food waste (a mixture of dairy and vegetable wastes; $n=13$ ), bovine slurry $(n=3)$, mixing tank $(n=8)$, raw digestate $(n=19)$ and dried digestate $(n=2)$ samples were collected from 3 separate commercial AD facilities located in the east of Ireland. These materials were not preselected but were the feedstock materials being used on the day of each visit. Each plant was visited on one occasion and the samples aseptically removed using a sterile scoop (Sterileware, Fisher Scientific Ireland, Dublin, Ireland) and sterile containers (VWR, Dublin, Ireland). All samples were transported to the laboratory in a cool box at $2-4{ }^{\circ} \mathrm{C}$ within $3 \mathrm{~h}$.

\subsubsection{Microbiological Analysis}

Exactly $25 \mathrm{~g}$ of each sample was diluted and/or enriched in $225 \mathrm{~mL}$ of diluent or broth before plating on selective agar and incubated at $37^{\circ} \mathrm{C}$ for $24 \mathrm{~h}$, unless otherwise indicated (Table 1). Presumptive colonies were confirmed using culture based and PCR methods (also Table 1). All media (except BBL Enterococcosel broth, which was supplied by Becton Dickinson (Limerick, Ireland)) were Oxoid products and purchased from Fannin Ltd., (Dublin, Ireland), as were the AnaeroGen sachets. Immunomagnetic separation (IMS) beads by Dynal ${ }^{\circledR}$ BeadRetriever were supplied by Thermo Fisher Scientific (Dublin, Ireland) while the Sifin anti-coli O157 sera test and defibrinated horse blood were provided by Cruinn Diagnostics Ltd., (Dublin, Ireland).

Table 1. The isolation and confirmation methods used to test the samples for the target bacteria.

\begin{tabular}{|c|c|c|c|}
\hline \multicolumn{2}{|c|}{ Detection } & \multicolumn{2}{|c|}{ Confirmation } \\
\hline Treatment & Selective Agar & Culture Based & Molecular \\
\hline \multicolumn{4}{|c|}{ Salmonella spp. } \\
\hline buffered peptone water & $\begin{array}{l}\text { modified semi-solid Rappaport } \\
\text { Vassiliadis medium with } \\
\text { novobiocin supplement }(20 \mathrm{mg} / \mathrm{L}), \\
\text { incubated at } 42^{\circ} \mathrm{C} \text { for } 24 \mathrm{~h}\end{array}$ & $\begin{array}{l}\text { Xylose lysine deoxycholate } \\
\text { (XLD) agar }\end{array}$ & $\begin{array}{l}\text { Pathmanathan } \\
\text { et al. [13] }\end{array}$ \\
\hline \multicolumn{4}{|c|}{ E. coli $\mathrm{O} 157$} \\
\hline $\begin{array}{c}\text { modified tryptone soya broth (mTSB) } \\
\text { containing cefixime }(50 \mu \mathrm{g} / \mathrm{L}) \text { and } \\
\text { vancomycin }(6 \mathrm{mg} / \mathrm{L})\end{array}$ & $\begin{array}{l}\text { Immunomagnetic separation with } \\
\text { plating on sorbitol MacConkey } \\
\text { agar supplemented with } \\
\text { cefixime-tellurite (CT-SMAC) }\end{array}$ & $\begin{array}{l}\text { Eosin methyl blue agar and } \\
\text { plate count agar (PCA) } \\
\text { followed by agglutination } \\
\text { testing using the Sifin } \\
\text { anti-coli O157 sera test }\end{array}$ & $\begin{array}{l}\text { Paton and } \\
\text { Paton [14]. }\end{array}$ \\
\hline \multicolumn{4}{|c|}{ L. monocytogenes } \\
\hline $\begin{array}{l}\text { half strength Fraser broth, incubated } \\
\text { overnight at } 30^{\circ} \mathrm{C} \text { followed by full } \\
\text { strength Fraser broth incubated at } \\
\quad 37^{\circ} \mathrm{C} \text { for } 48 \mathrm{~h}\end{array}$ & $\begin{array}{l}\text { Listeria Selective Oxford agar and } \\
\text { Brilliance Listeria agar (BLA), } \\
\text { incubated at } 37^{\circ} \mathrm{C} \text { for } 48 \mathrm{~h}\end{array}$ & PCA & Terzi et al. [15] \\
\hline \multicolumn{4}{|c|}{ E. faecalis } \\
\hline $\begin{array}{l}\text { BBL Enterococcosel broth and plated } \\
\text { on Slanetz and Bartley agar (SBA) } \\
\text { incubated at } 37^{\circ} \mathrm{C} \text { for } 24 \mathrm{~h} \text {, followed } \\
\text { by } 44^{\circ} \mathrm{C} \text { for an additional } 24 \mathrm{~h}\end{array}$ & $\begin{array}{l}\text { Pink colonies were streaked on } \\
\text { PCA and stabbed in rows into } \\
\text { well-dried bile aesculin agar plates, } \\
\text { incubated at } 44^{\circ} \mathrm{C} \text { for } 24 \mathrm{~h} \text {. }\end{array}$ & PCA & $\begin{array}{l}\text { Dutka-Malen } \\
\text { et al. [16] }\end{array}$ \\
\hline \multicolumn{4}{|c|}{ Clostridium spp. } \\
\hline $\begin{array}{c}\text { Maximum recovery diluent before } \\
\text { plating on reinforced clostridial agar } \\
(\mathrm{RCA}) \text { incubated anaerobically } \\
\text { (AnaeroGen sachets in BioMérieux } \\
\text { GENbox jars (Hampshire, UK) at } \\
37^{\circ} \mathrm{C} \text { for } 48 \mathrm{~h}\end{array}$ & $\begin{array}{c}\text { Columbia blood agar } \\
\text { supplemented with } 5 \% \\
\text { defibrinated horse blood }\end{array}$ & & Song et al. [17] \\
\hline
\end{tabular}




\subsection{Survival Studies}

\subsubsection{Inoculum Preparation}

Salmonella Newport, E. coli O157 (NCTC 12900), L. monocytogenes and E. faecalis (NCTC 12697) strains were obtained from the Teagasc culture collection. The $S$. Newport and L. monocytogenes strains had a streptomycin resistance $(1000 \mu \mathrm{g} / \mathrm{mL})$ marker to facilitate recovery. To prepare the inoculum, a culture bead from frozen storage was streaked on TSA and incubated at $37^{\circ} \mathrm{C}$ for $24 \mathrm{~h}$. A single colony was then selected and placed into $10 \mathrm{~mL}$ of tryptone soya broth (TSB; Oxoid, Fannin Ltd., Ireland) and incubated overnight at $37^{\circ} \mathrm{C}$. The culture obtained was centrifuged and washed 3 times with phosphate buffered saline (PBS; Oxoid, Fannin Ltd., Ireland), before resuspension in PBS and serially diluted to obtain a cell concentration of approximately $10^{5} \mathrm{cfu} / \mathrm{mL}$.

Freeze-dried C. sporogenes DSM 767 obtained from the Deutsche Sammlung von Mikroorganismen und Zellkulturen (DSMZ, Braunschweig, Germany) were rehydrated as per the instructions provided. Twenty tubes of cooked meat medium (CMM; Oxoid, Fannin Ltd., Ireland) broth (20 mL) were inoculated with $100 \mu \mathrm{L}$ rehydrated C. sporogenes, and incubated in an anaerobic cabinet for 12-18 h at $37^{\circ} \mathrm{C}$. Clostridium sporulation agar was prepared as described by [18] and placed in a Whitley A35 anaerobic chamber (Don Whitley Scientific, West Yorkshire, UK) overnight using the $\mathrm{ANO}_{2}$ gas mixture $\left(10 \% \mathrm{H}_{2}, 10 \% \mathrm{CO}_{2}\right.$ and $80 \% \mathrm{~N}_{2}$; Air Products Ireland, Dublin, Ireland) to exclude all oxygen. Aliquots $(300 \mu \mathrm{L})$ of the overnight CMM broth were then spread onto 300 plates of CSA (inside the anaerobic chamber) before transfer to anaerobic boxes (GenBOX jars; BioMérieux UK Ltd., Basingstoke, UK; AnaeroGen sachets; Oxoid, Fannin Ltd., Ireland) and incubated at $37{ }^{\circ} \mathrm{C}$ for $12 \mathrm{~d}$. The CSA plates were then inspected to ensure sufficient spore growth for harvesting. Spore harvesting took place in a laminar flow hood. Approximately $4-5 \mathrm{~mL}$ ice-cold sterile distilled water was placed onto the surface of the CSA plates, agitating the surface of the agar with a sterile spreader to release the spores. The suspension was then transferred to the next agar plate and the scraping process repeated. This method was repeated until spores had been harvested from all of the 300 CSA plates. The suspensions were pooled in $50 \mathrm{~mL}$ tubes, centrifuged at $7000 \mathrm{RPM}$ at $4{ }^{\circ} \mathrm{C}$ for $10 \mathrm{~min}$ and washed with iced water, reducing the amount of liquid over the course of repeated cycles until a spore suspension of approximately $10^{7}$ spores $/ \mathrm{mL}$ (estimated by phase contrast microscope examination), which was then confirmed by plating out on Columbia blood agar (CBA; Oxoid, Fannin Ltd., Ireland) with $5 \%$ defibrinated horse blood (Cruinn diagnostics, Ireland). The spore preparations ( $1 \mathrm{~mL}$ aliquots) were stored at $-80^{\circ} \mathrm{C}$. Prior to inoculation, spore preparations were thawed at room temperature, prior to heat treatment at $80^{\circ} \mathrm{C}$ for $10 \mathrm{~min}$ to ensure the exclusion of vegetative cells.

\subsubsection{AD Commercial Formulation Preparation}

Four feedstock mixtures; [1] 100\% food waste (primarily vegetable matter with small amounts of cooked meats and bakery product waste); [2] slurry (bovine) and food waste (1:3); [3] slurry and food waste (3:1) and [4] slurry and grease-trap waste (from restaurants) (2:1) were formulated on a volumetric basis as per the advice of our commercial AD stakeholders. Food waste was supplied by local restaurants, slurry by beef farms in counties Galway, Louth and Meath and grease-trap waste from the Bioenergy and Organic Fertilizer Services (BEOFS) AD plant in Camphill, County Kilkenny, Ireland. Before use all samples were tested to ensure the target bacteria were absent.

\subsubsection{The Laboratory Model System}

Exactly 70 model reactors were prepared for each of the four mixtures. Each contained $10 \mathrm{~mL}$ of fresh seed material (obtained from a commercial AD bioreactor) mixed with $20 \mathrm{~mL}$ of the feedstock material in a sterile $100 \mathrm{~mL}$ tube (Ramboldi tubes, VWR, Ireland). For each mixture, 14 tubes were randomly assigned to each of the bacteria being studied. The bacterial cells/spores, prepared as described above, were then added to $1 \mathrm{~mL}$ MRD to give a final concentration of approximately $10^{4}$ cells or approximately $10^{7}$ spores $/ \mathrm{mL}$. The tubes were then incubated anaerobically (GenBOX 
jars; bioMérieux UK Ltd., Basingstoke, UK; AnaeroGen sachets; Oxoid, Fannin Ltd., Ireland) at $37^{\circ} \mathrm{C}$. Duplicate tubes were removed periodically (0 (immediately after inoculation), 1, 2, 3, 4, 5 and $10 \mathrm{~d}$ ), from the vortexed tubes, the $\mathrm{pH}$ recorded (Eutech $\mathrm{pH} 150$ probe (Thermo Scientific, Waltham, MA, USA), which was calibrated using $\mathrm{pH} \mathrm{4,} 7$ and 10 standards prior to use) and the surviving cells/spores enumerated.

\subsubsection{Enumeration of Surviving Cells}

The extracted samples $(1 \mathrm{~mL})$ were diluted in $9 \mathrm{~mL}$ MRD and serial dilutions prepared. Surviving cells/spores were enumerated as described in Table 2. All media and the AnaeroGen sachets were Oxoid products and purchased from Fannin Ltd., (Dublin, Ireland). Streptomycin sulphate was obtained from Sigma Aldrich Ireland Ltd., (Wicklow, Ireland). Agar plates were incubated at $37^{\circ} \mathrm{C}$ for $24 \mathrm{~h}$, unless otherwise indicated.

Table 2. Methods for enumerating surviving cells or spores.

\begin{tabular}{ccc}
\hline & Enumeration & PCR Confirmation \\
\hline S. Newport & $\begin{array}{c}\text { XLD, supplemented with streptomycin } \\
\text { sulphate }(1000 \mu \mathrm{L} / \mathrm{g})\end{array}$ & Pathmanathan et al. [13] \\
\hline E. coli O157 & CT-SMAC & Paton and Paton [14]. \\
\hline L. monocytogenes & $\begin{array}{c}\text { BLA, supplemented with streptomycin } \\
\text { sulphate }(1000 \mu \mathrm{L} / \mathrm{g}) \text { incubated at } 37^{\circ} \mathrm{C} \\
\text { for } 48 \mathrm{~h}\end{array}$ & Terzi et al. [15]. \\
\hline E. faecalis & $\begin{array}{c}\text { SBA incubated at } 37^{\circ} \mathrm{C} \text { for } 24 \mathrm{~h}, \\
\text { followed by } 44^{\circ} \mathrm{C} \text { for a further } 24 \mathrm{~h}\end{array}$ & Dutka-Malen et al. [16]. \\
\hline C. sporogenes & $\begin{array}{c}\text { RCA, incubated anaerobically } \\
\text { (AnaeroGen sachets in BioMérieux } \\
\text { GENbox jars (Hampshire, UK) at } 37^{\circ} \mathrm{C} \\
\text { for } 48 \mathrm{~h}\end{array}$ & \begin{tabular}{c} 
Song et al. [17] and Morandi et al. [19]. \\
\hline
\end{tabular} \\
\hline
\end{tabular}

\subsection{Data Analysis}

The survival study, as described above, was performed in duplicate and repeated on three separate occasions. Bacterial counts were converted into $\log _{10} \mathrm{cfu} / \mathrm{mL}$ and the $\mathrm{T}_{90}$-values (the time required to achieve a $90 \%(1 \mathrm{log})$ reduction in the population) were determined by linear regression using GraphPad Prism 7 software (San Diego, CA, USA), considering each replicate Y-value as an individual point. Differences between slopes were examined using ANOVA and Tukey's multiple comparison tests (GraphPad Prism 7.02). Statistical significance was set at the 5\% level $(p<0.05)$.

\section{Results}

The results of the survey of commercial AD inputs and outputs are shown in Table 3. Salmonella spp. were detected in the food waste (3 positive out of 13 samples tested (3/13)), mixing tank (1/8) and raw digestate (5/19) samples. E. coli O157 was only detected in one sample (raw digestate). In contrast L. monocytogenes, E. faecalis and Clostridium spp. were common in food waste $(5,11$ and 10/13), slurry $(2,3$ and 2/3), mixing tank $(8,7$ and 8/8) and raw digestate (17, 18 and 17/19) samples. The latter two bacteria were also detected in the two dried digestate samples tested. 
Table 3. Detection of the target pathogens in the different types of samples.

\begin{tabular}{cccccc}
\hline Pathogen & Salmonella spp. & E. coli O157 & L. monocytogenes & E. faecalis & Clostridium spp. \\
\hline Type of samples & \multicolumn{7}{c}{ Pre anaerobic digestion } \\
\hline food waste (13) ${ }^{1}$ & $\begin{array}{c}\text { Positive } \\
(3)^{2}\end{array}$ & negative & $\begin{array}{c}\text { positive } \\
(5)\end{array}$ & $\begin{array}{c}\text { positive } \\
(11)\end{array}$ & $\begin{array}{c}\text { positive } \\
(10)\end{array}$ \\
\hline bovine slurry (3) & negative & negative & $\begin{array}{c}\text { positive } \\
(2)\end{array}$ & $\begin{array}{c}\text { positive } \\
(3)\end{array}$ & $\begin{array}{c}\text { positive } \\
(2)\end{array}$ \\
\hline mixing tank (8) & positive & negative & $\begin{array}{c}\text { positive } \\
(1)\end{array}$ & $\begin{array}{c}\text { positive } \\
(7)\end{array}$ & $\begin{array}{c}\text { positive } \\
(8)\end{array}$ \\
\hline raw digestate (19) & positive & post anaerobic digestion \\
dried digestate (2) & negative & nositive & $(17)$ & positive \\
$(18)$ & negative & negative & $\begin{array}{c}\text { positive } \\
(2)\end{array}$ & $\begin{array}{c}\text { positive } \\
(2)\end{array}$ \\
\hline
\end{tabular}

In the model $100 \mathrm{~mL}$ tubes, the $\mathrm{pH}$ of the food waste (100\%) and slurry and food waste (1:3) formulations decreased from $\mathrm{pH} 7.1$ to 5.8. and from $\mathrm{pH} 7.2$ to 6.0, respectively (data not shown). In contrast the $\mathrm{pH}$ values in the slurry and food waste (3:1) increased from $\mathrm{pH} 7.5$ to 8.0 while the $\mathrm{pH}$ was stable at $\mathrm{pH} 8.0$ in the slurry and grease-trap waste (2:1) over the $10 \mathrm{~d}$ of the study.

The results of the regression analysis are provided in Figure 2 and Table 4. An initial period of growth (1-3 d) was observed in food waste (100\%; S. Newport, E. coli O157 and C. sporogenes), slurry and food waste (1:3; S. Newport, E. coli O157 and E. faecalis), slurry and food waste (3:1; S. Newport and E. faecalis) and in slurry and grease-trap waste (2:1; E. coli O157). The time required toachieve a $1 \log$ reduction in the S. Newport and E. coli O157 populations ranged from 1.5-2.8 d, with significantly $(p<0.05)$ higher $\mathrm{T}_{90}$-values observed for slurry when combined with food (3:1) and grease-trap waste (2:1). In contrast, the $\mathrm{T}_{90}$-values for $L$. monocytogenes were significantly lower in these two formulations ( 3.5 and $3.1 \mathrm{~d}$, respectively) as compared to those obtained for the same bacteria in food waste (6.2 d) and slurry and food waste (1:3). The latter provided an environment where any reduction was minimal (slope $=0.04$ ), resulting in an estimated $23.5 \mathrm{~d}$ required to achieve a $90 \%$ population reduction. $T_{90}$-values for E. faecalis ranged from 2.2 to $6.6 \mathrm{~d}$ with the latter obtained in slurry and food waste (3:1). C. sporogenes $T_{90}$-values ranged from 2.4 to $9.1 \mathrm{~d}$, with significantly different values obtained in each of the formulations in the order of; slurry and grease-trap waste (2:1) $>$ food waste $>$ slurry and food waste (1:3) > slurry and food waste (3:1). 


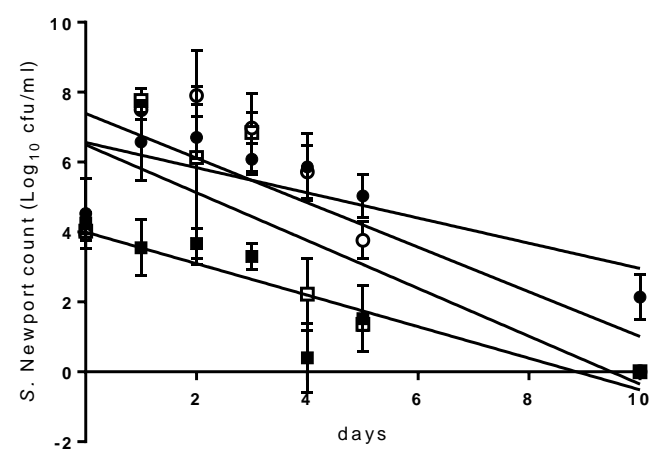

(A)

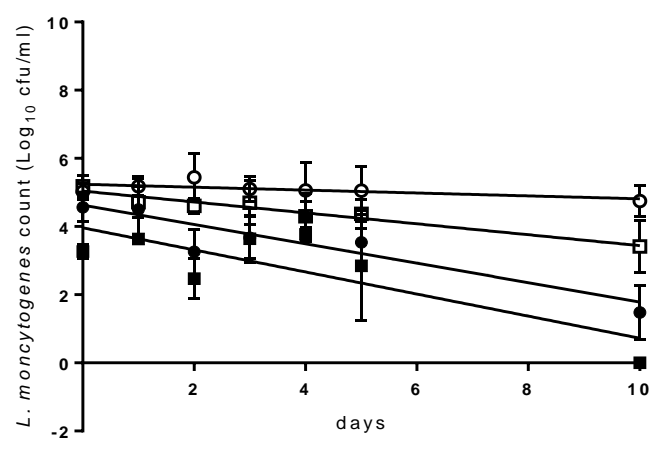

(C)

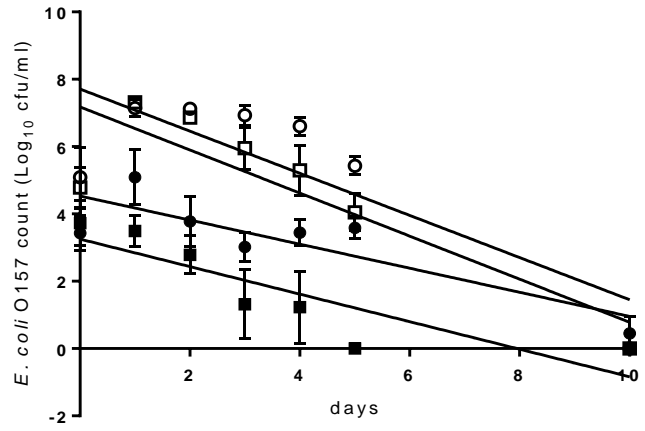

(B)

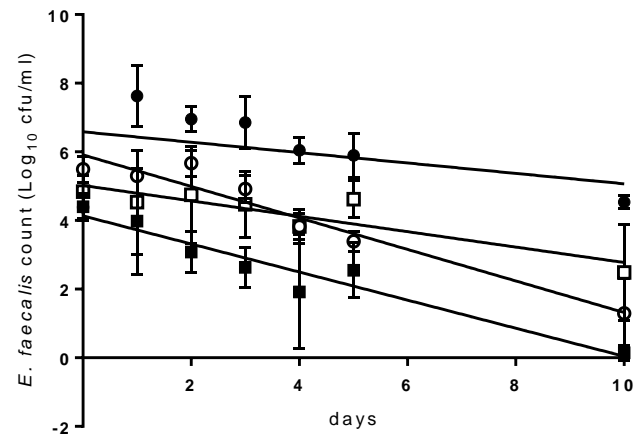

(D)

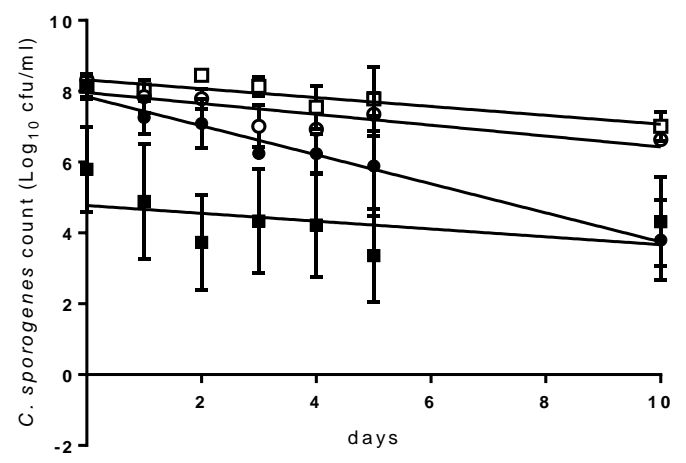

(E)

Figure 2. Linear regression graphs for Salmonella Newport (A), Escherichia coli O157 (B), Listeria monocytogenes (C), Enterococcus faecalis (D) and Clostridium sporogenes (E), in food waste ( $\square$ ), slurry and food waste $(1: 3)(\bigcirc)$; slurry and food waste $(3: 1)(\bullet)$ and slurry and grease-trap waste $(2: 1)(\boldsymbol{\square})$. Each point is the mean of 6 data points $(n=6)$ and the error bar is the standard deviation. 
Table 4. Observed growth and decay rate ( $\mathrm{T}_{90}$-values; the time for the bacterial concentration to decrease by 1 log unit) for the 5 pathogens (Salmonella spp., Escherichia coli O157, Listeria monocytogenes, Enterococcus faecalis and C. sporogenes) in the 4 different AD feedstock recipes.

\begin{tabular}{|c|c|c|c|c|c|c|c|c|c|}
\hline \multirow[b]{2}{*}{ Pathogen } & \multirow[b]{2}{*}{ Recipe } & \multicolumn{3}{|c|}{ Growth } & \multicolumn{5}{|c|}{ Decay Rate } \\
\hline & & Yes/No & Period & $\begin{array}{c}\text { Maximum } \\
\text { Concentration } \\
\left(\log _{10} \mathrm{cfu} / \mathrm{mL}\right)\end{array}$ & Slope & SE & $\begin{array}{c}\mathbf{R}^{2}- \\
\text { Value }\end{array}$ & $\begin{array}{c}T_{90} \text {-Value } \\
\text { (d) }\end{array}$ & $n$ \\
\hline \multirow[t]{4}{*}{ S. Newport } & ${ }^{1} \mathrm{FW}$ & yes & $1 \mathrm{~d}$ & 7.8 & -0.69 & 0.110 & 0.49 & $1.5^{\mathrm{A}}$ & 42 \\
\hline & ${ }^{2} \mathrm{SF} 1$ & yes & $1 \mathrm{~d}$ & 7.3 & -0.64 & 0.089 & 0.56 & $1.6^{\mathrm{A}}$ & 42 \\
\hline & ${ }^{3} \mathrm{SF} 2$ & yes & $1 \mathrm{~d}$ & 6.7 & -0.36 & 0.029 & 0.45 & $2.8^{\mathrm{B}}$ & 42 \\
\hline & ${ }^{4}$ SGW & no & ${ }^{5} \mathrm{NA}$ & ${ }^{6} \mathrm{NA}$ & -0.45 & 0.051 & 0.66 & $2.2^{\mathrm{B}}$ & 42 \\
\hline \multirow[t]{4}{*}{ E. coli $\mathrm{O} 157$} & FW & yes & $1 \mathrm{~d}$ & 7.3 & -0.64 & 0.062 & 0.77 & $1.6^{\mathrm{A}}$ & 42 \\
\hline & SF1 & yes & $1 \mathrm{~d}$ & 7.2 & -0.63 & 0.073 & 0.64 & $1.6^{\mathrm{A}}$ & 42 \\
\hline & SF2 & no & ND & NA & -0.36 & 0.044 & 0.62 & $2.8^{\mathrm{B}}$ & 42 \\
\hline & SGW & yes & $1 \mathrm{~d}$ & 5.1 & -0.41 & 0.049 & 0.64 & $2.5^{\mathrm{B}}$ & 42 \\
\hline \multirow[t]{4}{*}{ L. monocytogenes } & FW & no & ND & NA & -0.16 & 0.016 & 0.49 & $6.2^{\mathrm{B}}$ & 42 \\
\hline & SF1 & no & $\mathrm{ND}$ & NA & $7-0.04$ & 0.027 & 0.05 & $23.5^{C}$ & 42 \\
\hline & SF2 & no & ND & NA & -0.28 & 0.039 & 0.77 & $3.5^{\mathrm{A}}$ & 42 \\
\hline & SGW & no & ND & NA & -0.32 & 0.050 & 0.51 & $3.1^{\mathrm{A}}$ & 42 \\
\hline \multirow[t]{4}{*}{ E. faecalis } & FW & no & $\mathrm{ND}$ & NA & -0.22 & 0.053 & 0.31 & $4.5^{\mathrm{B}}$ & 42 \\
\hline & SF1 & yes & $1 \mathrm{~d}$ & 7.6 & -0.46 & 0.030 & 0.85 & $2.2^{\mathrm{A}}$ & 42 \\
\hline & SF2 & yes & $1 d$ & 7.6 & -0.15 & 0.060 & 0.14 & $6.6^{C}$ & 42 \\
\hline & SGW & no & $\mathrm{ND}$ & NA & -0.41 & 0.049 & 0.63 & $2.4^{\mathrm{A}}$ & 42 \\
\hline \multirow[t]{4}{*}{ C. sporogenes } & FW & yes & $3 \mathrm{~d}$ & 7.1 & -0.13 & 0.025 & 0.38 & $8.0^{\mathrm{C}}$ & 42 \\
\hline & SF1 & no & $\mathrm{ND}$ & NA & -0.15 & 0.024 & 0.50 & $6.5^{\mathrm{B}}$ & 42 \\
\hline & $\mathrm{SF} 2$ & no & ND & NA & -0.41 & 0.039 & 0.74 & $2.4^{\mathrm{A}}$ & 42 \\
\hline & SGW & no & $\mathrm{ND}$ & $\mathrm{NA}$ & -0.11 & 0.073 & 0.54 & $9.1^{\mathrm{D}}$ & 42 \\
\hline
\end{tabular}

${ }^{1} \mathrm{FW}=$ food waste ${ }^{2} \mathrm{SF} 1=$ slurry and food waste $(1: 3) ;{ }^{3} \mathrm{SF} 2=$ slurry and food waste $(3: 1) ;{ }^{4}$ SGW $=$ slurry and grease-trap waste $(2: 1) ;{ }^{5} \mathrm{ND}=$ not detected; ${ }^{6} \mathrm{NA}=$ not applicable; ${ }^{7}$ slope is very close to zero $(0.04)$ hence the $\mathrm{R}^{2}$ value is almost zero. Statistical analysis: for a given bacteria a different capital letter (A, B, C or D) indicates significantly different $\mathrm{T}_{90}$-values at the $5 \%$ level $(p<0.05)$.

\section{Discussion}

The commercial AD feedstock samples (food waste, bovine slurry and mixing tank materials) were contaminated with pathogens of public health significance including Salmonella spp., L. monocytogenes, E. faecalis and Clostridium spp. but not E. coli O157. Although there is little or no data for food waste or mixing tank materials, bovine faeces has been extensively tested and previous Irish studies have reported Salmonella spp. and L. monocytogenes contamination rates of 2-3\% [20,21] and 5-12\% [21,22], respectively, while $0.7-2.4 \%$ of samples are contaminated with E. coli O157 [23,24].

Salmonella and Clostridium spp. have also been detected in other AD feed materials $[5,7,25]$. To the best of our knowledge this is the first study reporting the presence of L. monocytogenes and E. faecalis, but this was not unexpected as these bacteria are widespread in the natural environment [26]. Of greater concern was the presence of all the target bacteria, including Salmonella spp. and E. coli O157, in raw digestate. Salmonella has been previously detected in digestate, suggesting these bacteria survive the AD process [5,7], although the possibility of post-reactor contamination cannot be ruled out. In contrast, only E. faecalis and Clostridium spp. were detected in the dried digestate, suggesting the drying process is sufficient to kill most but not all the bacteria of concern. This is an important finding, as several countries (including Ireland), have a standard requirement for the absence of Salmonella in $25 \mathrm{~g}$ before this material can be used as a fertiliser [7].

This study also investigated the survival of Salmonella spp., E. coli O157, L. monocytogenes, E. faecalis and Clostridium spp. in four $\mathrm{AD}$ feedstock formulations at $37^{\circ} \mathrm{C}$ in a small scale laboratory system. Although previously shown to be a useful study tool [12], laboratory-scale batch systems may not be representative of full-scale continuous commercial bioreactors due to differences in inoculation methods, 
rheology and hydrodynamic factors [27]. Moreover, as our feedstock mixtures were formulated on a volumetric basis, it is possible that the organic load could have been different between the various formulations. This would affect the production of VFAs, ethanol, ammonia, hydrogen disulphide, etc., by the bacteria present, thereby influencing pathogen survival. Thus, while the survival data obtained provides a good indication of the relative resistance of each bacteria in the materials and under the conditions tested, further research would be required to obtain a more accurate representation of how these organisms behave in large scale commercial systems.

The $T_{90}$-values for $S$. Newport ranged from 1.5 to $2.8 \mathrm{~d}$, regardless of the feed stock formulation. Interestingly, these values are similar to those previously reported for the decline of Salmonella spp. in the initial stages of the AD process, which typically range from $0.2 \mathrm{~d}$ in sewage sludge [28] to $7 \mathrm{~d}$ in a mixture of plant waste, cattle manure and cattle slurry [29-31]. The E. coli $\mathrm{O}_{157} \mathrm{~T}_{90}$ values (1.6-2.8 d) were similar to those of $S$. Newport and within the range of $0.5-6.5 \mathrm{~d}$ reported in previous AD pathogen survival studies [31-35]. Considering these bacteria survive for extended periods (at least 3 months) in bovine slurry [36,37] our data supports the hypothesis that AD is an effective process for Salmonella and E. coli O157 removal from animal waste.

In three of the four formulations the population of L. monocytogenes decreased by $1 \log _{10} \mathrm{cfu} / \mathrm{mL}$ after approximately 3-6 d but in slurry and food waste (1:3) the population was almost stable resulting in a regression slope close to zero (-0.04). While previous studies have reported typical $\mathrm{T}_{90}$-values of 1.5-2.2 d, in AD formulations [38-40], L. monocytogenes may also achieve a steady state during AD where the population is maintained for extended periods and the $T_{90}$ values are as high as $12.3 \mathrm{~d}$ in batch slurry and $35.7 \mathrm{~d}$ in semi-continuous digestion. This is not unexpected as L. monocytogenes have a host of molecular mechanisms that facilitate survival in a range of different environments [41]. The $\mathrm{T}_{90}$-value for E. faecalis ranged from 2.2 to $6.6 \mathrm{~d}$, with significantly higher endurance in food waste and in slurry and food waste (3:1). These values compare to the $0.1-7 \mathrm{~d}$ previously reported for Enterococcus spp. in different feed-stocks (dairy waste, cattle slurry, swine manure and sewage sludge) $[31-33,35,40,42,43]$ and is of particular significance as enterococci are considered to be good indicators of the fate of bacterial vegetative cells during $\mathrm{AD}$ [43]. C. sporogenes survival rates were lower than expected, with $\mathrm{T}_{90}$ values of 2.4-9.1 d. While comparable data for C. sporogenes is not available, Froschle et al. [25] found it required approximately $35 \mathrm{~d}$ to achieve a 1 log reduction in the population of Clostridium botulinum in laboratory scale digesters at $38{ }^{\circ} \mathrm{C}$, while Chauret et al. [40] observed no change in the concentration of $C$. perfringens in the mesophilic digestion of sewage sludge after 20 d. Our observations are inconsistent with these findings and may be the result of the experimental design, for example elevated carbohydrate concentrations stimulating early VFA production, but further investigation is required.

When the different formulations were compared the results were mixed and there was no one mixture that consistently provided higher or lower $\mathrm{T}_{90}$ values for all of the bacteria tested. Food waste, alone and when combined with slurry, supported an initial growth phase $(1 \mathrm{~d})$ for $S$. Newport, E. coli $\mathrm{O} 157$ and/or E. faecalis, which are metabolically similar under anaerobic conditions, but also provided the lowest $\mathrm{T}_{90}$-values for these bacteria. Interestingly, increasing the proportion of slurry in these mixtures resulted in significantly higher $\mathrm{T}_{90}$-values for these bacteria but the opposite was observed with L. monocytogenes and C. sporogenes. Thus, while the bacteria tested decreased, the reduction rate was dependent on factors other than the formulation, as previously reported [44].

\section{Conclusions}

It was concluded that $\mathrm{AD}$ feed materials might be contaminated with a range of bacterial pathogens. However given the large volumes used in commercial bioreactors these would be diluted out and present at very low concentrations. In the laboratory-scale batch system used in our experiments, the survival rates of $S$. Newport, E. coli $\mathrm{O} 157$ and E. faecalis were similar to those previously reported while C. sporogenes declined more rapidly than expected. This requires further investigation as does the 
ability of L. monocytogenes to survive for extended periods during $\mathrm{AD}$, perhaps necessitating mandatory pasteurisation of digestate.

Author Contributions: Conceptualization, D.B.; Methodology, D.B., L.R., P.W.; Formal Analysis, L.R., D.B.; Investigation, L.R.; Resources, D.B.; Data Curation, L.R., D.B.; Writing-Original Draft Preparation, D.B., L.R.; Writing-Review and Editing, D.B., L.R., P.W., A.Z., E.C., S.G., B.M., T.d.W., S.N., V.O., F.A., K.R., O.F.; Supervision, D.B., P.W.; Project Administration, D.B.; Funding Acquisition, D.B. All authors have read and agreed to the published version of the manuscript.

Funding: This study was funded by the Food Institute Research Measure administered by the Department of Agriculture, Food and Marine (Project 14/SF/487).

Acknowledgments: Lauren Russell was supported by the Teagasc Walsh Scholarship Programme (number 2014239).

Conflicts of Interest: The authors declare no conflict of interest.

\section{References}

1. Alkanok, G.; Demirel, B.; Onay, T.T. Determination of biogas generation potential as a renewable energy source from supermarket wastes. Waste Manag. 2014, 34, 134-140. [CrossRef]

2. Johansson, M.; Emmoth, E.; Salomonsson, A.C.; Albihn, A. Potential risks when spreading anaerobic digestion residues on grass silage crops-Survival of bacteria, moulds and viruses. Grass Forage Sci. 2005, 60, 175-185. [CrossRef]

3. Ramos-Suárez, J.; Arroyo, N.C.; González-Fernández, C. The role of anaerobic digestion in algal biorefineries: Clean energy production, organic waste treatment, and nutrient loop closure. In Algae and Environmental Sustainability; Singh, B., Kuldeep, B., Faizal, B., Eds.; Springer: New Delhi, India, 2015; pp. 53-76.

4. Anukam, A.; Mohammadi, A.; Naqvi, M.; Granström, K. A review of the chemistry of anaerobic digestion: Methods of accelerating and optimizing process efficiency. Processes 2019, 7, 504. [CrossRef]

5. Sidhu, J.P.S.; Toze, S.G. Human pathogens and their indicators in biosolids: A literature review. Environ. Int. 2009, 35, 187-201. [CrossRef]

6. Orzi, V.; Scaglia, B.; Lonati, S.; Riva, C.; Boccasile, G.; Alborali, G.; Adani, F. The role of biological processes in reducing both odor impact and pathogen content during mesophilic anaerobic digestion. Sci. Total Environ. 2015, 526, 116-126. [CrossRef] [PubMed]

7. Bonetta, S.; Bonetta, S.; Ferretti, E.; Fezia, G.; Gilli, G.; Carraro, E. Agricultural reuse of the digestate from anaerobic co-digestion of organic waste: Microbiological contamination, metal hazards and fertilizing performance. Water Air Soil Pollut. 2014, 225, 2046. [CrossRef]

8. Bonetta, S.; Ferretti, E.; Bonetta, S.; Fezia, G.; Carraro, E. Microbiological contamination of digested products from anaerobic co-digestion of bovine manure and agricultural by-products. Lett. Appl. Microbiol. 2011, 53, 552-557. [CrossRef] [PubMed]

9. Stutz, L.H. Risk Assessment of Input of Pathogens Residing in Co-Substrates into the River from Sewage Treatment Plant with Mesophilic Anaerobic Digestion. A Case Study of Salmonella and Campylobacter Evaluation in the Sewage Treatment Plant of Bern (ARA Bern). Bachelor's Thesis, Life Sciences and Facility Management, Swiss Federal Institute of Technology, Zurich, Switzerland, 2015.

10. Auer, A.; Burgt, N.H.V.; Abram, F.; Barry, G.; Fenton, O.; Markey, B.K.; Nolan, S.; Richards, K.; Bolton, D.; De Waal, T.; et al. Agricultural anaerobic digestion power plants in Ireland and Germany: Policy and practice. J. Sci. Food Agric. 2016, 97, 719-723. [CrossRef] [PubMed]

11. Avery, L.M.; Anchang, K.Y.; Tumwesige, V.; Strachan, N.; Goude, P.J. Potential for pathogen reduction in anaerobic digestion and biogas generation in sub-Saharan Africa. Biomass Bioenergy 2014, 70, 112-124. [CrossRef]

12. Nolan, S.; Waters, N.R.; Brennan, F.; Auer, A.; Fenton, O.; Richards, K.; Bolton, D.J.; Pritchard, L.; O’Flaherty, V.; Abram, F. Toward assessing farm-based anaerobic digestate public health risks: Comparative investigation with slurry, effect of pasteurization treatments, and use of miniature bioreactors as proxies for pathogen spiking trials. Fun. Environ. Micro. 2018, 2, 1-11. [CrossRef]

13. Pathmanathan, S.G.; Cardona-Castro, N.; Sanchez-Jimenez, M.M.; Correa-Ochoa, M.M.; Puthucheary, S.D.; Thong, K.L. Simple and rapid detection of Salmonella strains by direct PCR amplification of the hilA gene. J. Med. Microbiol. 2003, 52, 773-776. [CrossRef] [PubMed] 
14. Paton, A.W.; Paton, J.C. Detection and characterization of Shiga toxigenic Escherichia coli by using multiplex PCR assays for stx1, stx2, eaeA, enterohemorrhagic E. coli hlyA, rfbO111, and rfbO157. J. Clin. Microbiol. 1998, 36, 598-602. [CrossRef] [PubMed]

15. Terzi, G.; Gücükoğlu, A.; Çadirci, Ö.; Uyanik, T.; Alişarli, M. Serotyping and antibiotic susceptibility of Listeria monocytogenes isolated from ready-to-eat foods in Samsun, Turkey. Turkish J. Vet. Anim. Sci. 2015, 39, 211-217. [CrossRef]

16. Dutka-Malen, S.; Evers, S.; Courvalin, P. Detection of glycopeptide resistance genotypes and identification to the species level of clinically relevant enterococci by PCR. J. Clin. Microbiol. 1995, 33, 24-27. [CrossRef] [PubMed]

17. Song, Y.; Liu, C.; Finegold, S.M. Real-time PCR quantitation of clostridia in feces of autistic children. Appl. Environ. Microbiol. 2004, 70, 6459-6465. [CrossRef] [PubMed]

18. Casadei, M.A.; Ingram, R.; Skinner, R.J.; Gaze, J.E. Heat resistance of Paenibacillus polymyxa in relation to $\mathrm{pH}$ and acidulants. J Appl. Microbiol. 2000, 89, 801-806. [CrossRef]

19. Morandi, S.; Cremonesi, P.; Silvetti, T.; Castiglioni, B.; Brasca, M. Development of a triplex real-time PCR assay for the simultaneous detection of Clostridium beijerinckii, Clostridium sporogenes and Clostridium tyrobutyricum in milk. Anaerobe 2015, 34, 44-49. [CrossRef]

20. McEvoy, J.M.; Doherty, A.M.; Sheridan, J.J.; Blair, I.S.; McDowell, D.A. The prevalence of Salmonella spp. in bovine faecal, rumen and carcass samples at a commercial abattoir. J. Appl. Microbiol. 2003, 94, 693-700. [CrossRef]

21. Madden, R.H.; Murray, K.A.; Gilmour, A. Carriage of four bacterial pathogens by beef cattle in Northern Ireland at time of slaughter. Lett. Appl. Microbiol. 2007, 44, 115-119. [CrossRef]

22. Fox, E.; O’Mahony, T.; Clancy, M.; Dempsey, R.; O’Brien, M.; Jordan, K. Listeria monocytogenes in the Irish dairy farm environment. J. Food Prot. 2009, 72, 1450-1456. [CrossRef]

23. McEvoy, J.M.; Doherty, A.M.; Sheridan, J.J.; Thomson-Carter, F.M.; Garvey, P.; McGuire, L.; Blair, I.S.; McDowell, D.A. The prevalence and spread of Escherichia coli O157:H7 at a commercial beef abattoir. J. Appl. Microbiol. 2003, 95, 256-266. [CrossRef] [PubMed]

24. Thomas, K.M.; McCann, M.S.; Collery, M.M.; Logan, A.; Whyte, P.; McDowell, D.A.; Duffy, G. Tracking verocytotoxigenic Escherichia coli O157, O26, O111, O103 and O145 in Irish cattle. Int. J. Food Microbiol. 2012, 153, 288-296. [CrossRef] [PubMed]

25. Froschle, B.; Messelhausser, U.; Holler, C.; Lebuhn, M. Fate of Clostridium botulinum and incidence of pathogenic clostridia in biogass processes. J. Appl. Microbiol. 2015, 119, 936-947. [CrossRef] [PubMed]

26. Colleran, E. Hygienic and sanitation requirements in biogas plants treating animal manures or mixtures of manures and other organic wastes. In Anaerobic Digestion: Making Energy and Solving Modern Waste Problems; Ørtenblad, H., Ed.; AD-NETT, Herning Municipal Authoritie: Herning, Denmark, 2000; pp. 77-86.

27. Hofmann, J.; Müller, L.; Weinrich, S.; Debeer, L.; Schumacher, B.; Velghe, F.; Liebetrau, J. Assessing the effects of substrate disintegration on methane yield. Chem. Eng. Technol. 2020, 43, 47-58. [CrossRef]

28. Riau, T.; De la Rubia, M.A.; Pérez, M. Temperature-phased anaerobic digestion (TPAD) to obtain class A biosolids: A semi-continuous study. Bioresour. Technol. 2010, 101, 2706-2712. [CrossRef] [PubMed]

29. Kunte, D.P.; Yeole, T.Y.; Ranade, D.R. Inactivation of Vibrio cholera during anaerobic digestion of human night soil. Bioresour. Technol. 2000, 75, 149-151. [CrossRef]

30. Termorshuizen, A.J.; Volker, D.; Blok, W.J.; ten Brummeler, E.; Hartog, B.J.; Janse, J.D.; Knol, W.; Wenneker, M. Survival of human and plant pathogens during mesophilic digestion of vegetable, fruit and garden waste. Eur. J. Soil Biol. 2003, 39, 156-171. [CrossRef]

31. Santha, H.; Sandino, J.; Shrimp, G.F.; Sung, S. Performance evaluation of a sequential-batch temperature-phased anaerobic digestion (TPAD) Scheme for producing class A biosolids. Water Environ. Res. 2006, 78, 221-226. [CrossRef]

32. Olsen, J.E.; Larsen, H.E. Bacterial decimation times in anaerobic digestions of animal slurries. Biol. Wastes 1987, 21, 153-168. [CrossRef]

33. Cote, C.; Masse, D.I.; Quessy, S. Reduction of indicator and pathogenic microorganisms by psychrophilic anaerobic digestion in swine slurries. Bioresour. Technol. 2006, 97, 686-691. [CrossRef]

34. Higgins, M.J.; Chen, Y.; Murthy, S.N.; Hendrickson, D.; Farrel, J.; Schafer, P. Reactivation and growth of non-culturable indicator bacteria in anaerobically digested biosolids after centrifuge dewatering. Water Res. 2007, 41, 665-673. [CrossRef] [PubMed] 
35. Masse, D.; Gilbert, Y.; Topp, E. Pathogen removal in farm-scale psychrophillic anaerobic digesters processing swine manure. Bioresour. Technol. 2011, 102, 641-646. [CrossRef] [PubMed]

36. Nicholson, F.A.; Groves, S.J.; Chambers, B.J. Pathogen survival during livestock manure storage and following land application. Bioresour. Technol. 2005, 96, 135-143. [CrossRef] [PubMed]

37. McGee, P.; Bolton, D.J.; Sheridan, J.J.; Earley, B.; Leonard, N. The survival of Escherichia coli O157:H7 in slurry from cattle fed different diets. Lett. Appl. Microbiol. 2001, 32, 152-155. [CrossRef]

38. Kearney, T.E.; Larkin, M.J.; Frost, J.P.; Levett, P.N. Survival of pathogenic bacteria during mesophilic anaerobic digestion of animal waste. J Appl. Microbiol. 1993, 75, 215-219. [CrossRef]

39. Horan, N.J.; Fletcher, L.; Betmal, S.M.; Wilks, S.A.; Keevil, C.W. Die-off of enteric pathogens during mesophilic anaerobic digestion. Water Res. 2004, 38, 1113-1120. [CrossRef]

40. Chauret, C.; Springthorpe, S.; Sattar, S. Fate of Cryptosporidium oocysts, Giardia cysts and microbial indicators during wastewater treatment and anaerobic sludge digestion. Can. J. Microbiol. 1999, 45, 257-632. [CrossRef]

41. Gahan, C.; Hill, C. Listeria monocytogenes: Survival and adaptation in the gastrointestinal tract. Cell. Infect. Microbiol. 2014, 4, 1-7. [CrossRef]

42. Pepper, I.L.; Brooks, J.P.; Sinclair, R.G.; Gurian, P.L.; Gerba, C.P. Pathogens and indicators in United States Class B biosolids: National and historic distributions. J. Environ. Qual. 2010, 39, 2185-2190. [CrossRef]

43. Viau, E.; Peccia, J. Survey of wastewater indicatorsand human pathogen genomes in biosolids produced byclass A and class B stabilization treatments. Appl. Environ. Microbiol. 2009, 75, 164-174. [CrossRef]

44. Smith, S.R.; Lang, N.L.; Cheung, K.H.M.; Spanoudaki, K. Factors controlling pathogen destruction during anaerobic digestion of biowastes. Waste Manag. 2005, 25, 417-425. [CrossRef] [PubMed]

(C) 2020 by the authors. Licensee MDPI, Basel, Switzerland. This article is an open access article distributed under the terms and conditions of the Creative Commons Attribution (CC BY) license (http://creativecommons.org/licenses/by/4.0/). 